logue at Paris. The UK has one foot already in the camp of the OPEC which, as Wilson observed in Rome, is not a joke for the EC, because its own interests and those of OPEC are directly opposed to each other. In the long view, it is true, there are a few hopeful prospects contained in the compromise resolution; including a floor price for crude oil, and the willingness of France to cooperate in setting up an emergency programme. For the time being, the "wise compromise" does not mean at all that the EC will make itself heard at the Paris "North-South" Conference with a single voice. The EC will only be represented there by a single delegation of nine delegates - but the sum total of them will be 1 plus 8 , and it is not impossible that further splits will break up the nine into more splinters.

In view of the unending conflict of interests within the EC, it is only to be hoped that, in the long run, the sarcastic pun of Gustav Thorn, President of the UN General Assembly, will not always remain a portrait of the truth: "Many UN delegations do no longer speak of the Common Market but of the Common Bazaar."

\section{Energy Policy}

\section{Iranian Natural Gas for Western Europe}

Towards the end of November, after hard bargaining an agreement was concluded in Teheran about the supply of Iranian natural gas to Western Europe. The gas is to be delivered by pipeline via Soviet Russia and Czechoslovakia. Signatories to the deal were Iranian, Soviet, Austrian, French and German representatives. The value of the supplies to be delivered until 2003 is in today's prices somewhere in the neighbourhood of DM 40 bn; roughly DM 10 bn must be spent on the pipeline system.

That the negotiations could be successfully concluded is essentially due to the fact that each of the partners will profit by the deal: Iran will have an assured market for some 13 bn cubic metres of its gas, the Soviet Union through the proposed pipeline network increases its transport flexibility in the South and South-East of the country and the West European states make sure of part of their energy requirements. The Federal Republic of Germany, being one of the leading pipe producers, has the additional possibility of making money by selling pipes. It is therefore hardly surprising that after the signing of the deal satisfaction reigned allround.

Inside Germany, however, critical voices were heard pointing to the renewed danger of becoming dependent in the vital field of energy. But this need hardly be taken seriously. For, in the first place, the share of natural gas in the primary energy consumption of 1985 will be no more than 15 p.c. to 18 p.c., and, secondly, only 7 p.c. of Germany's total consumption of natural gas will come from Iran. A more positive attitude towards the new pact would seem to be more reasonable, for the agreement has laid the foundation of a new international interconnected system. For the sectors of railway and electricity such an interlinking has long become a much-praised blessing as much as a matter of course; why should it not be possible and desirable in the field of natural gas?

iwe

\section{East Africa \\ Afro-Chinese Brotherhood}

If Tanzania had its way, it would sooner or later establish a socialist community of states with Zambia and Mozambique. Agreement in outline has already been reached between Tanzania and Mozambique on what forms such cooperation should take.

That Tanzania should seek closer links with its southern neighbours is only natural, for both these adjoining states steer a socialist course on the lines of the Chinese People's Republic. In this area China's rating is high, and this not only on account of the Tanzam Project. It looks as if the Africans would warmly welcome cooperation with the Chinese, not least because China, being itself a "non-European developing country", is showing them a way towards economic development. This, it is felt, is in tune with their desire for Africanization. China may well be the example which proves that loyal cooperation at all levels, mutual understanding, organizational talent and labour-intensive development aid are together more effective than individual capital-intensive and technically perfect prestige projects.

The question then arises to what extent it will be possible to reconcile Tanzania's new plan with its membership of the East-African Community (EACSO). There can be only one answer to this question - not at all. For the constant political row with Idi Amin's Uganda and the antagonism between Kenya and Tanzania over the infrastructural establishments the two countries run jointly show that EACSO is destined to break down; only the date of the divorce has not yet been fixed.

From a purely economic point of view divorce from Kenya may be a mistake, for, although Tanzania's social structure would seem to be much fairer, the standard of living of its people has hardly risen in the past ten years, in marked contrast to living conditions in prosperous Kenya. What political and economic consequences a cooperation between socialist Afro-Asian brothernations will produce remains to be seen. 